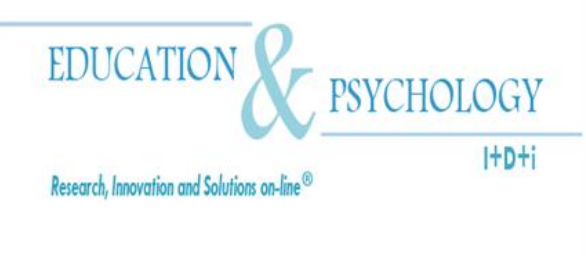

\title{
Contrasting Academic Behavioural Confidence in Mexican and European Psychology Students
}

\section{Alma Rosa Águila Ochoa ${ }^{1}$, Paul Sander $^{2}$}

\footnotetext{
${ }^{1}$ Universidad Nacional Autónoma de México, México, D.F.

${ }^{2}$ Psychology, Cardiff Metropolitan University, Cardiff, Wales
}

\section{Mexico / United Kingdom}

Correspondence: Paul Sander, Psychology, Cardiff Metropolitan University, Llandaff Campus, Western Avenue, Cardiff, Wales, UK. E-mail: psander@cardiffmet.ac.uk

(C) Education \& Psychology I+D+i and Editorial EOS (Spain) 


\begin{abstract}
Introduction. Research with the Academic Behavioural Confidence scale using European students has shown that students have high levels of confidence in their academic abilities. It is generally accepted that people in more collectivist cultures have more realistic confidence levels in contrast to the overconfidence seen in individualistic European and North American countries. This research was designed to see if the more realistic confidence level in collectivist countries would be mirrored in Mexican students' academic confidence scores.
\end{abstract}

Method. The Academic Behavioural Confidence scale was validated in the Mexican university system with a sample of 97 undergraduates at a large autonomous university and the findings contrasted with pre-existing data from 2685 European students.

Results. The results suggest that a reduced 14 item scale comprising the same 4 subscales, Grades, Studying, Verbalising and Attendance is the statistically preferable model for both the Mexican and European data. Using the mean confidence levels for the modified subscales, it was found that the Mexican psychology students had significantly higher Grades and Verbalising confidences than their European counterparts.

Discussion and Conclusion. This contra-prediction finding is considered against the literature from cultural and cross cultural psychology which suggests that people in Collectivist cultures like México have more connected attitudes to their lives and thus would show lower but more realistic self-confidence. Further research to establish the cross cultural validity of the $\mathrm{ABC}$ scale is discussed.

Keywords: Academic Behavioural Confidence, Self-efficacy, Culture, Collectivism, Overconfidence bias.

Received: 03/15/11 Initial acceptance: 06/12/12 Final acceptance: 07/07/12 


\section{Comparación de la confianza de la conducta académica en estudiantes de psicología mejicanos y europeos}

\section{Resumen}

Introdución. La investigación con la escala de Conducta de Confianza Académica con los estudiantes europeos ha demostrado que los estudiantes tienen altos niveles de confianza en sus habilidades académicas. En general se acepta que la gente en culturas más colectivistas tienen niveles de confianza más realistas en contraste con el exceso de confianza se ve en individualistas países de Europa y América del Norte. Esta investigación fue diseñada para ver si el nivel de confianza más realista en los países colectivistas se refleja en las puntuaciones de confianza académica de los estudiantes mexicanos.

Metódo. Un grupo de 97 alumnos de primer año de psicología en UNAM, respondieron la escala $\mathrm{ABC}$ en condiciones similares a estudios previos. Usando análisis factorial confirmatorio en AMOS, descubrimos una estructura factorial similar a lo encontrado anteriormente. Con algunas modificaciones pudimos tener un modelo con las mismas 4 sub-escalas usando 14 reactivos que describen mejor los resultados anteriores y los datos mexicanos.

Resultados. Contrariamente a las predicciones esperadas, descubrimos que los alumnos de UNAM tuvieron confianza más alta en sub-escalas de Calificaciones y Verbalización.

Discusión y conclusiones. Los resultados no son como predecibles así son considerados contra de la literatura de la psicología cultural que sugiere que las personas en culturas colectivistas como México están más conectadas a las actitudes de sus vidas y por lo tanto muestran una confianza mas baja en sí mismas, pero mas realista. Se necesitan investigaciones adicionales para estableces la validez transcultural de la escala $\mathrm{ABC}$ que están aún en discusión.

Palabras Clave: Confianza, auto-eficacia, cultura, colectivismo 


\section{Introduction}

Sander, Stevenson, King and Coates (2000) suggested that understanding the confidence that students have towards their studies could be important for making sense of students' expectations of teaching, learning and assessment. It was from this that the Academic Behavioural Confidence (ABC) scale was developed and tentatively positioned against the established constructs of self concept and self-efficacy (see Sander, 2009; Sander \& Sanders, 2003, 2006, 2009). Academic Behavioural Confidence is a variant of academic self-efficacy, in that it refers to cognitive judgements concerned specifically with the expectation of competence in future academic related behaviours in undergraduate students (e.g. attending lectures, independent study and so forth). Unlike self-efficacy beliefs, academic behavioural confidence does not distinguish between competence beliefs in different academic domains, but between different undergraduate study-related behaviours, such as confidence in independent study, attaining grades, discussing course material and questions and academic engagement though attending formal sessions, (Nicholson, Putwain, Connors, \& HornbyAtkinson, in press).

The ABC scale itself started out as a psychometric means of assessing the confidence that United Kingdom (UK) undergraduate university students on largely lecture-based courses have in their own anticipated study behaviours in relation to the degree programmes that they are following. As such, the scale was developed to try to understand how students view themselves in terms of confidence to be successful within the large student groups that many UK university lecturers have to teach. The rationale was that knowing students' $\mathrm{ABC}$ scores, along with other profile measures could play an important part in enabling teachers to better understand their students and could help lecturers to optimise their teaching styles and target more effective provision of student support (for example, Cassidy \& Eachus, 2000; De la Fuente \& Justicia, 2007; Sander, 2004).

Exploratory and confirmatory factor analysis with a large sample of UK students has shown that the ABC scale is best understood as consisting of four subscales: Grades, Verbalising, Studying and Attendance (Sander, 2009; Sander \& Sanders, 2009). Using that subscale structure, it has been shown that the $\mathrm{ABC}$ scale (UK version) meaningfully discriminates between students on different courses. Students on courses with higher entry requirements 
such as Medicine, Speech and Language Therapy and Nutrition have higher confidence in one or more of the Grades, Studying and Attendance subscales (Sander \& Sanders, 2009). Further studies using the ABC scale show that male students are more confident than female students on the subscales Grades, Verbalising and Studying, in line with previous research (see Hartley, Betts, \& Murray, 2007; Sanders, Sander, \& Mercer, 2009). The difference in verbalising confidence between male and female students, particularly in tutorial settings, is supported by a substantial literature (Read, Archer, \& Leathwood, 2003; Somners \& Lawrence, 1992; Sternglanz \& Lyberger-Ficek, 1997). Thirdly, data summarised by Sander (2009) shows that dyslexic students in UK higher education have lower academic confidence on the Grades, Verbalising and Studying subscales but neither female students nor dyslexic students showed significantly lower academic confidence on the Attendance subscale which could be interpreted as evidence for these students having equivalent commitment to their studies. Fourthly, ABC scores correlate with academic performance (Nicholson et al, in press) although it is anticipated that the correlation between academic confidence and academic performance will be low as confidence is seen as a presage factor and performance as product. Intervening the two are process factors such as approach to learning and selfregulation (Biggs, 2003). Fifthly, there is evidence that students have higher academic confidence (Sander, 2009) than would be expected under normative reasoning, in line with research on general confidence (Alicke, Klotz, Breitenbecher, Yurak \& Vredenburg, 1995; Plous, 1993). Finally, data show that ABC scores drop during a course of study (Sander, 2009), in line with other research findings (Beyer, 1998/1999; Papinczak, Young, Groves, \& Haynes, 2008; Zusho, Pintrich, \& Coppola, 2003).

Taken together, these five substantial findings suggest that the ABC scale could be very useful in identifying individual students or groups of students at risk and/or being used as part of a battery of measures to better understand students in the Higher Education. If there are similar findings in students from other countries, the usefulness of the ABC scale can be extended into those countries. Erasmus links with universities in Spain lead to substantial, Spanish government funded, research that produced the Spanish version of the ABC scale (Sander, de la Fuente, Stevenson \& Jones, 2011). Findings from this research are included in the summary above. A similar link in México, along with the validated Spanish version of the $\mathrm{ABC}$ scale gave an opportunity to use the scale in a very different, non European cultural context. 
In México the family and work based groups are paramount. First comes the relationships and then any work or home based jobs. These differences can be evidenced through the results of Hofstede's research into employees of IBM (Hofstede, 2001; internet source) which shows Mexico low on Individualism and high on Collectivism which is manifest in a close long-term commitment to the member groups like the family or work placed groups. Loyalty in a collectivist culture is paramount, and over-rides most other societal rules and regulations. Mexico is also: high on Uncertainty Avoidance which is a low level of tolerance for uncertainty which leads to, strict rules, laws, policies, and regulations; high on Masculinity scores indicating that the country experiences a high degree of gender differentiation of roles and; high in Power Distance which is indicative of a high level of inequality of power and wealth within the society.

México has an expanding higher education system which has been changing over the last 60 years to increase inclusivity, both in terms of the numbers of young people progressing to university and the backgrounds from which they come. As such, an elitist system is being turned into one that makes university education more open to young people, including young people from families with few resources. Whilst in 1950 only $1 \%$ of those aged between 19 and 23 went to university, more than one in three people aged 19 to 23 were going to university in 2010-11 and the government has the aspiration to raise that level to $48 \%$ (Oca, 2006; Tuirán, 2011a). For comparison, Chile and Argentina have 55\% and 68\% respectively of people aged 19-23 going to university (Tuirán, 2011a). In contrast with countries like Brazil and Chile which have increased student numbers through private university provision, México has increased provision through the expansion of the public university system (Tuirán, 2011b).

That México is more collectivist than any European country (Goodwin \& Hernandez Plata, 2000; Gouveia \& Ros, 2000; Heydenfeldt, 2000; Morling and Lamoreaux, 2008; Shkodriani and Gibbons, 1995; Tafarodi \& Walters, 1999) is significant as research shows that confidence or efficacy beliefs are generally lower when there are low Individualism, high Collectivism scores (Goodwin \& Hernandez Plata, 2000; Hetts, Sakuma \& Pelham, 1999; Klassen, 2004; Oyserman, Coon and Kemmelmeier, 2002; VonDras, 2005), linked to the fact that people in Collectivist cultures have different conceptions of the self in general (Markus \&Kitayama, 1991). This has been shown in studies using both survey techniques, for exam- 
ple, Kwan, Bond and Singelis (1997) and more experimental approaches, for example as reported in Marcus and Kitayama (1991) which have shown that within cultures with high Individualism scores like the United States and Europe, people have higher levels of confidence in their abilities than people in more Collectivist cultures like Japan and México where selfeffacement is culturally important and the norm. To illustrate, Marcus and Kitayama report that the Japanese estimated that about $50 \%$ of students would be better than they were or have more of a given trait or ability like memory, athletic ability, independence, and sympathy which is what would be expected from nonbiased, normative reasoning whereas American students assumed that only $30 \%$ of people on average would be better than themselves on those traits and abilities. Given that the construct Academic Behavioural Confidence has been aligned with self-efficacy (Sander \& Sanders, 2006; Sander, 2009; Nicholson et al, in press), Mexican university students could be expected to respond lower on the ABC scale than the UK university students on which the scale has been developed, underpinned by the fact that Mexican university students have strong Collectivism beliefs (Shkodriani \& Gibbons, 1995).

Empirical research is required to establish whether the ABC scale, as used with a Mexican university sample, has an equivalent factor structure to that found in European students. Without that check, using the ABC scale in the Mexican university sector would be an imposed etic (Smith, Bond, \& Kagitcibasi, 2006) or at least the naïve transference of a construct and/or a measure across cultures. The ABC scale structure would be supported if a suitably translated Spanish version yields data from a Mexican sample with a similar underlying factor structure.

\section{Objetives}

1. To seek to explore the appropriateness of the four subscale conception of the Spanish translation of the ABC scale with data from psychology students studying at a large autonomous university in México Distrito Federal (México City).

2. To contrast the academic confidence of the Mexican student with similar European university students to test the hypothesis that they will have lower and arguably more realistic levels of academic confidence (Marcus \& Kitayama, 1991). 


\section{Method}

\section{Participants}

The participants in this study were 97 undergraduate students of psychology in their first semester at the Universidad Nacional Autónoma de México (UNAM), or about one third of the total main campus based (Ciudad Universitaria) first year cohort. Whilst demographic data was not collected, the sex distribution was normal for undergraduate psychology class with a substantial majority of female students and their age was typical too, in their late teens or early twenties.

Design

This study was survey based with students being asked to complete two psychometric scales.

\section{Instruments}

Students were asked to complete two scales, one measuring academic confidence and the other the students' approach to learning. This report confines itself to reporting the findings relating to academic confidence, measured through the Academic Behavioural Confidence scale. The Academic Behavioural Confidence Scale (Sander \& Sanders, 2009; Sander, de la Fuente, Stevenson \& Jones, 2011, see appendix A) was modified by omitting item 19, "Make the most of the opportunity of studying for a degree at university" because when the Spanish version of the ABC scale was piloted with a volunteer sample of students in Universidad Nacional Autónoma de México (UNAM) almost all were unable to respond to it. When asked to explain, the students all said that either they did not understand the question or did not know how to respond on the 5-point Likert scale. The students expanded to say that now that they were in university and a prestigious, highly sought after university, they were not looking for more opportunities ${ }^{1}$. The scale was re-numbered accordingly (see Table 1) to give a 23 item scale.

\footnotetext{
${ }^{1}$ This view has to be contrasted with the typical UK student seeking the "university experience" of partying and socialising. These Mexican students had worked exceedingly hard and gained a place in UNAM against stiff competition. They were there to work. That is why they were at university. Thus the question made no sense to them.
} 
All analyses were at the subscale level, computed as shown in Table 1. Research with a large UK sample (Sander \& Sanders, 2009) has shown the internal reliability of the four subscales to be at least adequate, with Cronbach's alpha values of .78 for Grades, .78 for Verbalising, .72 for Studying and .74 for Attendance. A critical consideration of the validity of the ABC scale can be found in Sander (2009) and Sander, de la Fuente, Stevenson and Jones (2011). The scale had previously been translated into Spanish by a professional translator in the field of educational psychology in Almería, Spain. Three Spanish professors in the area of psychology and education worked with the translator, to ensure the appropriateness of the translation. This process included back translation.

Table 1. The Academic Behaviour Confidence sub scales.

$\begin{array}{llll}\text { Grades } & \text { Verbalising } & \text { Studying } & \text { Attendance }\end{array}$

\begin{tabular}{|c|c|c|c|}
\hline $\begin{array}{l}\text { [2]Produce your best } \\
\text { work under examina- } \\
\text { tion conditions }\end{array}$ & $\begin{array}{l}\text { [3]Respond to ques- } \\
\text { tions asked by a lec- } \\
\text { turer in front of a full } \\
\text { lecture theatre }\end{array}$ & $\begin{array}{l}\text { [1] Study effectively on } \\
\text { your own in independ- } \\
\text { ent / private study }\end{array}$ & $\begin{array}{l}\text { [6]Attend most taugh } \\
\text { sessions }\end{array}$ \\
\hline
\end{tabular}

[7]Attain good grades in your work

[15]Produce coursework at the required standard.

[16]Write in an appropriate academic style.

\section{[5]Give a presentation to a small group of fellow students}

[8]Engage in profitable academic debate with your peers

[10]Ask lecturers questions about the material they are teaching, during a lecture
[4]Manage your work load to meet coursework deadlines

[18]Be on time for lectures.

\section{[21-UNAM20]Plan appropriate revision schedules.}

[24-UNAM23]Attend tutorials

\section{[20-UNAM19]Pass assessments at the first attempt.}

[23-UNAM22]Produce your best work in coursework assignments

\section{[22-UNAM21]Remain} adequately motivated throughout.

The table shows the sub scale composition. The items after 18 are renumbered to show the item number used in this study but the original item numbers are retained for consistency with other publications using this scale. Items in italics were those removed in the revised 14 item ABC scale and the two in bold are the two an error covariance in the final model as presented in the results. 


\section{Procedure}

The psychology students were approached through their regular class lecturer and were invited to volunteer to complete two psychometric scales designed to give a measure of behaviour and attitudes related to their academic studies. It was explained that the research was part of a much larger project that had been running for a number of years in Spain and the UK. The formal instructions on completing the scales were given to the students by the first author at the start of one of their scheduled teaching sessions. One completion of the scales, the students were given a brief explanation of the reseach. Questions were invited and answered.

\section{Data Analysis}

The data was analysed by confirmatory factor analysis (CFA) using AMOS, version 17, (Arbuckle, 2006) to test the 4 factor model that had emerged from previous research (Sander, de la Fuente, Stevenson and Jones, 2011; Sander and Sanders, 2009). The results from CFA were considered using Chi-squared as recommended by Barrett (2007) and also the absolute fit statistics: Comparative Fit Index (CFI), Tucker-Lewis coefficient (TLI) and Root Mean Square Error of Approximation (RMSEA) noting that with small samples RMSEA over-rejects the true model (Tabachnick and Fidell, 2007). The expected crossvalidation index (ECVI), as a comparative fit index, was used to facilitate the comparison of the models from pre-existing data. To interpret the output statistics, CFI and TLI values close to 1 indicate a very good fit, RMSEA values less than .05 indicate a good fit and values as high as .08 represent reasonable errors of approximation in the population (Byrne, 2001), and the lower the ECVI value the better the model (Mackenzie, Knox, Gekoski, \& Macauley, 2004) when single sample data is considered.

It is acknowledged that the Mexican sample size maybe considered small but Tabachnick and Fidell (2007) argue that SEM can be possible with sample sizes as small as 60 (p.683). The Chi-Squared statistic with large sample sizes can lead to false significant effects and with small sample sizes there can also be inaccurate probability levels (Fan, Thompson and Wang, 1999; Tabachnick and Fidell, 2007). The absolute fit statistics are relatively independent of sample size, if less easy to interpret (Barrett, 2007). However, the Mexican sample data are not presented in isolation but considered against a further sample of 2685 psy- 
chology undergraduates. As Tabachnick and Fidell (2007) say, cross-validation with another sample can avoid many of the problems of interpretation of fix indices.

Subsequently in SPSS 17.0.0 (2008), the data were analysed with appropriate parametric statistical tests to explore inter-university differences with pre-existing data. All analyses were at the subscale level, with the mean value on the five-point ( 1 to 5$)$ scale being reported.

\section{Results}

\section{Reliability}

The first step in the data analysis was to measure the acceptability of the internal reliability of the four ABC subscales. Using Cronbach's alpha, it was found that the alpha values were: Grades, .785 (.785); Verbalising, .762 (.762); Studying .615 (.622) and Attendance, .496. The alpha coefficients in brackets are for the reduced scales where applicable, as discussed below. The low alpha value for Attendance is attributable to the almost certainty expressed that students would attend classes $(\mathrm{ABC} 6$, mean=4.79, $\mathrm{SD}=.455)$ and the very high but more variable responses for attending on time $(\mathrm{ABC} 18$, mean=4.24, $\mathrm{SD}=.955)$ and attending tutorials $(\mathrm{ABC} 23$, mean $=3.93, \mathrm{SD}=.904)$.

\section{The factor structure of the ABC scale in the UNAM sample}

Confirmatory factor analysis in AMOS was used to test the goodness of fit of the 17 item, 4 factor ABC model. The fit statistics suggested that this model was not well supported by the data (Chi-Squared $=168.095, \mathrm{df}=113, \mathrm{P}<.0001 \mathrm{CFI}=.880, \mathrm{TLI}=.856, \mathrm{RMSEA}=.071$ and $\mathrm{ECVI}=2.938$.

Subsequently the regression weights were inspected and three scales items, 1, 2 and 5 (see table 1, items in italics), with low loadings were deleted. CFI was re-run with substantially better results: Chi-Squared $=96.231, \mathrm{df}=71, \mathrm{p}<.05, \mathrm{CFI}=.933, \mathrm{TLI}=.914, \mathrm{RMSEA}=.061$ and ECVI=2.002 suggesting that this reduced item model was a good fit to the data. That the fit indices differentiate between the models for the UNAM $(n=97)$ sample suggest that the possible problems with a small sample size, discussed by Tabachnick and Fidell (2007) are not applicable here. Running CFA with Modification Indices suggested that a very good fit 
could be obtained by considering an error between $\mathrm{ABC} 19$ and $\mathrm{ABC} 20$. This model is shown in figure 1.

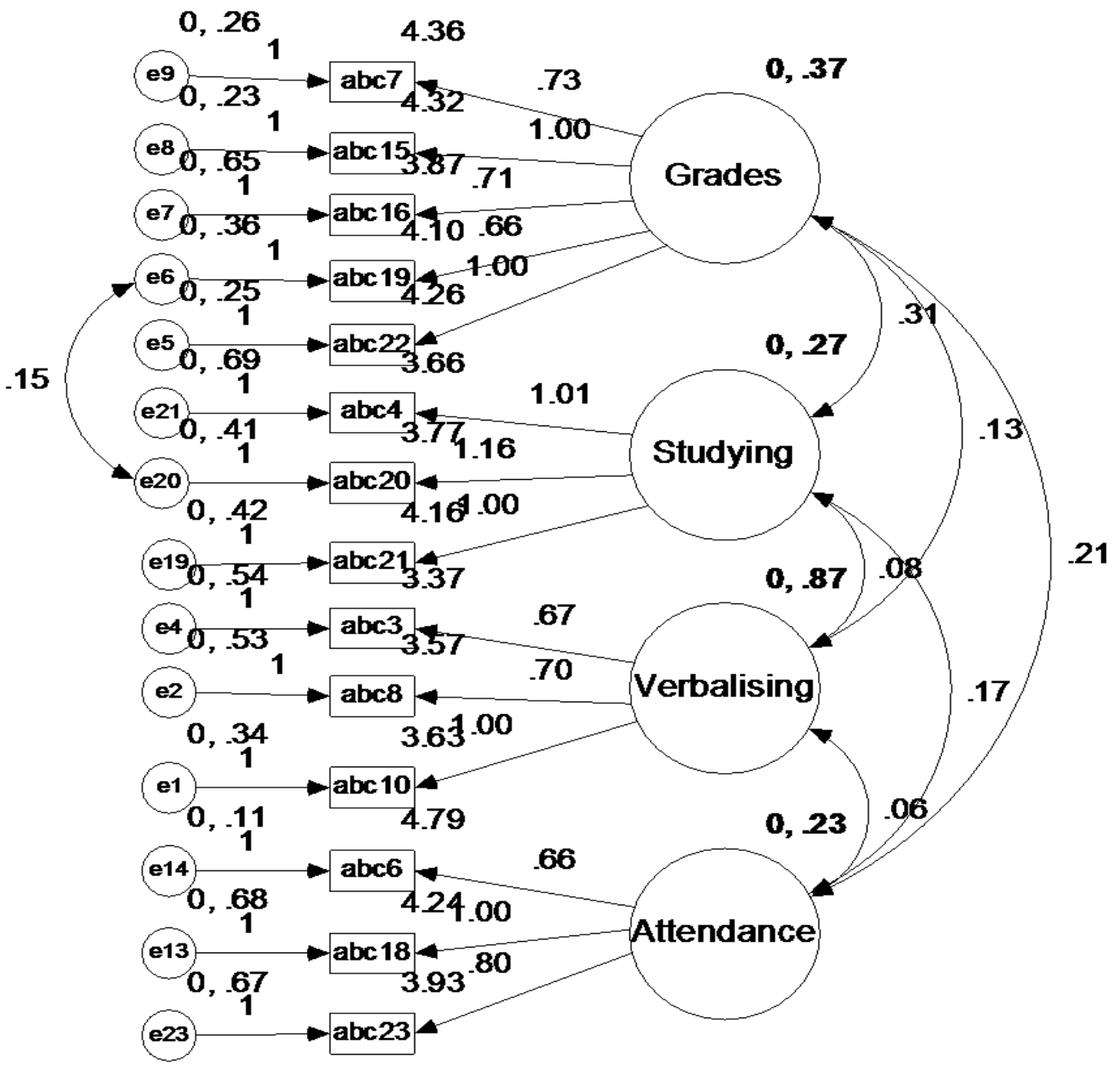

Figure 1. CFA standardised output for the reduced 14 item, 4 subscale ABC model

To validate this reduced 14 item scale, previous ABC data sets from the UK (Sander and Sanders, 2009), from Spain (Sander, de la Fuente, Stevenson and Jones, 2011) and a data set currently being compiled from a longitudinal study in two UK universities, were fitted to this model using CFA in AMOS. For all data sets the reduced 14 item (13 item from the Spanish data set as item 24 was accidentally omitted in the original study) is better than the previously considered 17 item scale and the addition of the error covariance between ABC19 and $\mathrm{ABC} 20$ (in bold in table 1) makes no appreciable difference for any data set other than the UNAM sample (see table 2). To assess whether this error covariance is a statistical artefact or has some theoretical basis, the two statements "Pass assessments at the first attempt" and "Plan appropriate revision schedules" were considered to go together well and thus a 
covariance could be expected. Indeed, perhaps the surprise is that for the other data sets there is not a commensurate improvement with the error covariance included.

Table 2. Model comparisons

\begin{tabular}{|c|c|c|c|c|c|c|c|c|}
\hline Data set & Model & $\begin{array}{l}\text { Chi- } \\
\text { squared }\end{array}$ & DF & $\mathbf{P}$ & CFI & TLI & RMSEA & ECVI \\
\hline \multirow{3}{*}{$\begin{array}{l}\text { UWIC } \\
\mathbf{n}=\mathbf{8 6 2} \\
\text { Data collected } \\
\text { 2000 onwards } \\
\text { Multi-sample } \\
\text { data set }\end{array}$} & 17 items & 506.790 & 113 & $\mathrm{P}<.0001$ & .913 & .883 & .064 & .719 \\
\hline & 14 items & 332.941 & 71 & $\mathrm{P}<.0001$ & .930 & .896 & .065 & .496 \\
\hline & $\begin{array}{l}14 \text { items With } \\
\text { error covarian- } \\
\text { ce }\end{array}$ & 327.510 & 70 & $\mathrm{P}<.0001$ & .931 & .896 & .065 & .493 \\
\hline \multirow{3}{*}{$\begin{array}{l}\text { Spanish Data }^{2} \\
\text { psychology } \\
\mathbf{n}=\mathbf{1 4 6 8} \\
\text { universities of } \\
\text { Almería and } \\
\text { Granada and } \\
\text { therefore multi- } \\
\text { sample. There is } \\
\text { no ABC } 24\end{array}$} & 16 items & 594.121 & 98 & $\mathrm{P}<.0001$ & .901 & .863 & .050 & .342 \\
\hline & 13 items & 375.517 & 59 & $\mathrm{P}<.0001$ & .922 & .880 & .051 & .225 \\
\hline & $\begin{array}{l}13 \text { items With } \\
\text { error covarian- } \\
\text { ce }\end{array}$ & 371.510 & 58 & $\mathrm{P}<.0001$ & .922 & .877 & .051 & .226 \\
\hline \multirow[b]{3}{*}{$\begin{array}{l}\text { Longitudinal } \\
\text { data } \\
\text { Autumn psy- } \\
\text { chology } \\
\text { n=211 } \\
\text { Longitudinal } \\
\text { study, 2010-11 } \\
\text { Universities of } \\
\text { Edge Hill and } \\
\text { UWIC Therefore } \\
\text { multi-sample }\end{array}$} & 17 items & 222.299 & 113 & $\mathrm{P}<.0001$ & .900 & .865 & .053 & .978 \\
\hline & 14 items & 131.251 & 71 & $\mathrm{P}<.0001$ & .930 & .897 & .050 & .661 \\
\hline & $\begin{array}{l}14 \text { items With } \\
\text { error covarian- } \\
\text { ce }\end{array}$ & 131.092 & 70 & $\mathrm{P}<.0001$ & .929 & .894 & .050 & .666 \\
\hline \multirow[b]{3}{*}{$\begin{array}{l}\text { Longitudinal } \\
\text { data } \\
\text { Spring } 2011 \\
\text { psychology } \\
\text { n=144 } \\
\text { Longitudinal } \\
\text { study, 2010-11 } \\
\text { Universities of } \\
\text { Edge Hill and } \\
\text { UWIC Therefore } \\
\text { multi-sample }\end{array}$} & 17 items & 192.290 & 113 & $\mathrm{P}<.0001$ & .900 & .864 & .045 & .890 \\
\hline & 14 items & 123.571 & 71 & $\mathrm{P}<.0001$ & .920 & .882 & .046 & .638 \\
\hline & $\begin{array}{l}14 \text { items With } \\
\text { error covarian- } \\
\text { ce }\end{array}$ & 122.525 & 70 & $\mathrm{P}<.0001$ & .920 & .880 & .047 & .641 \\
\hline \multirow{3}{*}{$\begin{array}{l}\text { UNAM autumn } \\
2010 \text { psychology } \\
\text { n=97 }\end{array}$} & 17 items & 168.095 & 113 & $\mathrm{P}<.0001$ & .880 & .856 & .071 & 2.938 \\
\hline & 14 items & 96.231 & 71 & $\mathrm{P}<.05$ & .933 & .914 & .061 & 2.002 \\
\hline & $\begin{array}{l}14 \text { items With } \\
\text { error cova- } \\
\text { riance }\end{array}$ & 85.291 & 70 & .104 & .960 & .974 & .048 & 1.908 \\
\hline
\end{tabular}

For each of 5 data sets, three models are considered; the original (Sander and Sanders 2009) 17 item model, the 14 item model stemming from the UNAM data and the same 14 item model with error co-variances between errors 4 and 16.

\footnotetext{
${ }^{2}$ There are 13 statements here as a clerical error led to ítem 24 being omitted from the scale. This is the same 14 item scale as presented for the other data sets but with item 24 (Attendance) missing.
} 
With the 14 item, four factor ABC model, the Mexican sample could be compared with pre-existing European data in which new subscale means the 14 item subscales scores had been calculated for this analysis.

UNAM data against other comparable student samples

Following the hypothesis that people in more Collectivist countries would have lower selfefficacy and thus confidence, the UNAM ABC statistics were compared with psychology students in three European universities, Granada and Almería in Spain and UWIC in Cardiff, UK (table 3).

Table 3. Means and standard deviations (SD) for the 4 Academic Behavioural Confidence subscales for the three European samples and the one Mexican sample of psychology undergraduates.

$\begin{array}{llcccc}\text { Cardiff } & \text { Mean } & \text { Grades } & \text { Verbalising } & \text { Studying } & \text { Attendance } \\ & \text { SD } & (.59) & 3.10 & 3.79 & \mathbf{4 . 4 3} \\ \text { Granada } & \text { Mean } & 3.54 & 3.10 & (.60) & (.62) \\ & \text { SD } & (.55) & (.88) & 3.76 & 4.19 \\ \text { Almería } & \text { Mean } & 3.52 & 3.14 & 3.77 & (.77) \\ & \text { SD } & (.55) & (.78) & (.54) & 4.19 \\ \text { UNAM } & \text { Mean } & \mathbf{4 . 1 8} & \mathbf{3 . 5 2} & 3.87 & 4.32 \\ & \text { SD } & (.58) & (.58) & (.68) & (.57)\end{array}$

The means in bold are significantly larger than the others.

Using a one way analysis of variance, three of the four subscales showed a statistically significant difference in Academic Behavioural Confidence scores, albeit with small effect sizes (Tabachnick and Fidell, 2007, p55): Grades $\left(F_{3,1803}=43.389, p<.0001, \eta_{p}{ }^{2}=.067\right)$, Verbalising $\left(\mathrm{F}_{3,1803}=7.684, \mathrm{p}<.0001, \eta_{\mathrm{p}}{ }^{2}=.014\right)$, and Attendance $\left(\mathrm{F}_{3,1803}=8.633, \mathrm{p}<.0001\right.$, $\left.\eta_{\mathrm{p}}^{2}=.014\right)$. Scheffé's post hoc tests shows that for Grades and Verbalising the UNAM students are significantly more confident than those from Cardiff, Almería and Granada. For Attendance, the Cardiff students were significantly more confident that the students from Almería and Granada. 
Single sample t-tests show that all the subscale means for each university sample are significantly greater than the scale midpoint of 2.5 on which the students rated their confidence $(\mathrm{p}<.0001)$.

\section{Discussion}

The study set out to consider the applicability of the Academic Behavioural Confidence scale in a Mexican university setting. Confirmatory factor analysis resulted in good statistical evidence for a reduced 14 factor ABC scale which is applicable to not just the UNAM sample but also extant and comparable samples from Wales and Spain (see appendix B for the final version of the $\mathrm{ABC}$ scale with subscales indicated).

The Mexican data was best described by a slightly different model that had an error covariance which requires consideration. Is there something special about the Mexican university environment that might lead to a slightly different factorial model? The competition for places Universidad Nacional Autónoma de México (UNAM) is very high. Once on a course, there is a great incentive to achieve good grades as students are assessed through their attendance and participation in class as well as in coursework, presentations and interim and final exams. Therefore there is good reason to believe that the UNAM sample is indeed different from the European samples and as such the amendment to the model by including an error covariance justified. However, omitting the error covariance still leaves a very good model.

A secondary aim of the study was the comparison of the Academic Behavioural Confidence between the Mexican students with comparable European students. The first point to note in this respect is, assuming that the students saw the scale midpoint as representing average confidence, UNAM students, like their European counterparts (Sander, 2009), are significantly above average in their confidence levels for all four subscales which is in contrast to what might be expected from the Collectivistic Mexican students. Also, there is a broadly similar pattern of confidence in that all university samples have highest confidence for Attendance and lowest for Verbalising. For the European students, Studying confidence is greater than Grades confidence but that order is reversed for the Mexican sample whose Academic Behavioural Confidence rank order from highest to lowest is Attendance, Grades, Studying 
and Verbalising whereas for the European students it is Attendance, Studying, Grades and Verbalising.

In general people in Asia, Latin America and southern Europe have a different understanding of the self (Markus and Kitayama, 1991) and in particular, Mexicans have different ways of, for example, negotiating to US Americans which reflects different cultural attitudes in line with Collectivism and Individualism (Heydenfeldt, 2000). With a sample of university students, Shkodriani and Gibbons (1995) showed that Mexican university students are more collectivist than their US counterparts, using the Individualism-Collectivism scale (Hui, 1988). Kwan, Bond and Singelis (1997) found that within Collectivist Hong Kong, students had lower self-esteem scores measured by the Rosenberg Self-Esteem Inventory (Rosenberg, 1965). Taken together, it was predicted that Collectivist Mexican students would have lower ABC scores but this was not found. The UNAM sample showed a comparable overconfidence bias and was significantly more confident for Grades and Verbalising than the European university samples.

There could be a number of non-exclusive explanations unpredicted finding. First, there is evidence that there is good cross-cultural generalisability of the concept of the academic self (Brunner, Keller, Hornung, Reichert, \& Martin, 2009). Second, a university setting may not be representative of a culture at large (see Hetts, Sakuma and Pelham, 1999 and Oyserman, Coon and Kemmelmeier, 2002 for a discussion on the self in culture) and foster domain specific, individualistic thinking, supported by Hetts, Sakuma and Pelham (1999) who showed that Individualism and Collectivism could be primed. The university environment could do just that - prime individualistic thinking. Certainly the ABC scale asks respondents specifically about themselves in relation to their own education and not to think about their lives within a cultural context, in relation to others. Thus, Collectivism could well have been less salient with the focus on the self in relation to study behaviours, divorced from others and cultural expectations. If that is the case, one would not expect lower Academic Behavioural Confidence in undergraduate students in more Collectivist cultures or situations. Thirdly, students studying in UNAM could have been exposed to more individualistic values (see discussion by Morling and Lamoreaux, 2008) which would influence their understanding of themselves in relation to their studies. Finally, the Mexican sample might appear to be involved in an individualist pursuit, to achieve well at university but not for themselves; rather for the prestige and financial benefits that the family could accrue. Thus academic 
success, reflected in high confidence levels could have social or Collectivist origins. Marcus and Kitayama (1991) contrast individually oriented achievement motivation and socially oriented achievement motivation. Thus, on the surface one may see the same behaviours which reflect similar confidence levels but the behaviours are driven by very different motives.

Following the arguments above, the UNAM psychology undergraduates might not be expected to have lower $\mathrm{ABC}$ scores but this study has found that they had higher $\mathrm{ABC}$ scores. Is it that that UNAM attracts exceptional students or at least students with exceptional confidence in their academic studies? UNAM is ranked $222^{\text {nd }}$ in the world and first in Latin America with Granada, Spain more than two hundred places below at 451 (Top University, 2010) which could render the UNAM psychology students more confident in themselves and their studies and reflect that they had to have achieved more to have attained a place at such a prestigious university. However, this argument does not hold for the equivalence in student ABC scores from Granada, Almería and UWIC as UWIC and Almería do not make the world top 600 on the Top University list yet these students are similarly confident to the psychology students from the University of Granada, ranked 451, although this is potentially explainable through a floor effect.

In earlier work (Sander, de la Fuente, Stevenson and Jones, 2011), it had been expected to find a confidence differences between Almería and Granada (Spain) on the one hand and UWIC on the other, on a similar collectivist argument, with southern Europe being more collectivist that northern Europe, but a difference in ABC scores was not found. The fact that a comparable university sample in a very Collectivist culture showed higher academic confidences on Grades and Verbalising sub scales suggests the possibility of a degree of domain specificity in thinking about Individualism and Collectivism. Further research is required to understand the relationship between academic confidence and university status or prestige and course status, prestige and entry requirements.

A final comment is that given that there was no difference between the student samples in the three countries, México, Spain and the UK, in Studying confidence, it might reflect that all students were confidently committed to their university studies.

The applicability of the $\mathrm{ABC}$ scale within the México university system has been demonstrated and has led to a more refined, 14 item $\mathrm{ABC}$ scale which has shown some inter- 
esting inter-university differences and replicated the over confidence bias found with $\mathrm{ABC}$ (Sander, 2009). However, the data comes from only a single sample of Mexican psychology students in a top Latin American university. It would be useful to measure ABC in other Latin American universities. Any future research could usefully measure self esteem (Rosenberg 1965) as well to see how that varies against ABC. In a Welsh sample, ABC has been found to correlate with self-esteem (Maziarz, 2011) but more importantly in a cultural context, it would be beneficial to see how both general self-esteem and specifically ABC vary with Collectivism, which should, perhaps, itself be measured explicitly. First, though, running focus groups to collect rich qualitative data to try and understand these Collectivist students in relation to their academic studies and their culture in line with Sanders, Sander and Mercer, (2009) is likely to be productive.

It would be interesting to explore whether Mexican undergraduates too show the same Academic Behavioural Confidence characteristics as European ones, with male students being more confident than female students; high entry requirement courses having students with higher Academic Behavioural Confidence levels; with dyslexic students having lower Academic Behavioural Confidence levels; that Academic Behavioural Confidence drops over time; that there is generally an over-confidence bias and that Academic Behavioural Confidence correlates with academic performance.

The ABC scale can also be used working individually with students. For example, it could be part of students' Personal and Professional Development plan as completing the $\mathrm{ABC}$ scale and reflecting on it could be useful for the students to help them realize the factors that their teachers may take into account or believe are important aspects of study. Completing the ABC scale would help students to recognise appropriate academic behaviour which maybe the students had not realised or developed sufficiently. Once a student has recognised the need for and developed the necessary skills, they can be extended into other modules or courses and, of course a great number of the skills identified in the $\mathrm{ABC}$ scale are equally applicable within the workplace. When working at an individual level, any responses that a student might give could be affected by any success or difficulties the student may be experiencing at that moment so caution would have to be exercised in interpreting any responses.

For teachers, it could be useful to know individual student's responses to the items on the $\mathrm{ABC}$ scale as it could help them identify the major points of difficulty for their students. 
With that insight, teachers can specifically support the students and help them develop appropriate academic skills. When teaching large classes, it could be of benefit for teachers to realise the range of confidences that their students have and to take that into account when teaching and giving advice and guidance. 


\section{Acknowledgements}

Special thanks are extended to Dirección General de Orientación y Servicios Educativos (DGOSE) in Universidad Nacional Autónoma de México (UNAM) for its support in enabling this investigation and the subsequent writing of this paper. Without the support of DGOSE this article would not have been possible.

Much of the European data was collected under the auspices of:

RD\&I Project ref. BSO2003-06493. Improving self-regulated learning in university students through online regulatory strategies for teaching. Ministry of Science and Technology, Spain (2003-2006) and Social Fund FEDER (EU).

RD\&I Project ref. SEJ2007-66843/educ. The assessment of improvement in the teachinglearning process and of competencies, in the European Space for Higher Education: Model and Protocols. Ministry of Education and Science, Spain (2007-2010) and Social Fund FEDER (EU).

R \&D Project ref. EDU2011-24805. Motivational-affective strategies of personal selfregulation and stress coping in university learning. Ministry of Education and Science, Spain (2012-2014) and Social Fund FEDER (EU).

\section{References}

Alicke, M. D.; Klotz, M. L.; Breitenbecher, D. L.; Yurak, T. J. \&Vredenburg, D. S. (1995). Personal contact, individuation and the better than average effect. Journal of Personality and Social Psychology, 68(5), 804-825.

Arbuckle, J. L. (2006). Amos 7.0 User's Guide. Chicago: SPSS.

Barrett, P. (2007). Structural equation modelling: Adjudging model fit. Personality and Individual Differences, 42, 815-824

Beyer, S. (1998/1999). Gender differences in causal attributions by college students of performance on course examinations. Current Psychology, 17, 346-358.

Biggs J. (2003), Teaching for Quality Learning at University, 2nd Edition, Buckingham: Society for Research into Higher Education/Open University Press.

Brunner, M., Keller, U., Hornung, C., Reichert, M., \& Martin, R. (2009). The cross-cultural generalizability of a new structural model of academic self-concepts. Learning and Individual Differences, 19, 387-403. 
Byrne, B. (2001). Structural equation modelling in AMOS: Basic concepts, applications, and programming. Mahwah, NJ: Lawrence Erlbaum.

Cassady, S., \& Eachus, P. (2000). Learning style, academic belief systems, self-report student proficiency and academic achievement in higher education. Educational Psychology, 20 (3), 307-322.

de la Fuente, J., \& Justicia, F. (2007). The DEDEPRO model for regulating teaching and learning: Recent advances. Electronic Journal of Research in Educational Psychology, 5(3), 535-564.

Fan, X., B. Thompson, \&L. Wang. (1999). "The Effects of Sample Size, Estimation Methods, and Model Specification on SEM Fit Indices." Structural Equation Modeling: A Multidisciplinary Journal, 6, 56-83.

Goodin, R., \& Hernandez Plata, P. (2007). Perceived and received social support in two cultures: Collectivism and support among British and Spanish students. Journal of Social and Personal Relationships, 17(2), 282-291

Gouveia, V. V., \& Ros, M. (2000). Hofstede and Schwartz's models for classifying Individualism at the cultural level: Their relation to macro-social and macro-economic variables. Psicothema, 12 (25)-33

Hartley, J., Betts, L., \& Murray, M. (2007). Gender and assessment: Differences, similarities and implications. Psychology Teaching Review, 13(1), 34-47.

Hetts,J. J., Sakuma, M. and Pelham, B. W. (1999). Two Roads to Positive Regard: Implicit and Explicit Self-Evaluation and Culture. Journal of Experimental Social Psychology, 35, 512-559

Heydenfeldt, J.A.G. (2000). The Influence of Individualism/Collectivism on Mexican and US business negotiation. International Journal of Intercultural Relations, 24, 383407.

Hofstede, G. (2001). Culture's Consequences, Comparing Values, Behaviors, Institutions, and Organizations Across Nations, Thousand Oaks CA: Sage Publications.

Hofstede, G. (internet source) http://www.geert-hofstede.com/hofstede_mexico.shtml, accessed August 4, 2011.

Hui, H. C. (1988). Measurement of Individualism-Collectivism. Journal of Research in Personality, 22, 17-36.

Klassen, R. M. (2004). A cross-cultural investigation of the efficacy beliefs of South Asian immigrant and Anglo non-immigrant early adolescents. Journal of Educational Psychology, 96, 731-742 
Kwan, V. S. Y., Bond, M. H. \& Singelis, T. M. (1997). Pancultural Explanations for Life Satisfaction: Adding Relationship Harmony to Self-Esteem. Journal of Personality and Social Psychology, 73(5), 1038-1051.

Mackenzie, C. S., Knox, V. J., Gekoski, W. L., \& Macauley, H. L. (2004). An adaptation and extension of the Attitudes Towards Seeking Professional Psychological Help Scale. Journal of Applied Social Psychology, 34(11), 2410-2435.

Markus, H. \& Kitayama, S. (1991). Culture and the Self: Implications for cognition, emotion and motivation. Psychological Review, 98, 224-253.

Maziarz, J. (2011). The Relation between Achievement Goal Orientation and the Self among Higher Education Students. Unpublished undergraduate dissertation, University of Wales Institute, Cardiff.

Morling, B. \&Lamoreaux, M. (2008). Measuring Culture Outside the Head: A Meta-Analysis of Individualism-Collectivism in Cultural Products. Personality and Social Psychology Review, 12(3), 199-221.

Nicholson, L.J., Putwain, D.W., Connors, L., \& Hornby-Atkinson, P. (in press). The key to successful achievement as an undergraduate student: confidence and realistic expectations? Studies in Higher Education, 38(5).

Oca, J. R., (2006). La Política Educativa y la Educación Superior en México, 1995-2006: Un balance. Secretaría de Educación Pública. Retrieved on April 4th, 2011 from http://ses2.sep.gob.mx/aye/ocde/pees/pees.pdf

Oyserman, D. Coon, H.M. \&Kemmelmeier, M. (2002). Rethinking Individualism and Collectivism: Evaluation of Theoretical Assumptions and Meta-Analyses. Psychological Bulletin, 128(1), 3-72.

Papinczak, T., Young, L., Groves, M., \& Haynes, M. (2008). Effects of a metacognitive intervention on students' approaches to learning and self-efficacy in a first year medical course. Advances in Health Sciences Education, 13(2), 213-232.

Plous, S. 1993. The Psychology of Judgement and Decision Making. New York, McGraw Hill.

Read, B., Archer, L., \& Leathwood, C. (2003). Challenging cultures? Student conceptions of 'belonging' and 'isolation' at a post-1992 university. Studies in Higher Education, 28, 261-277.

Rosenberg, M. (1965). Society and the Adolescent Self-Image. Princeton, N.J.: Princeton University Press 
Sander, P. (2004). Increasing student numbers: Diminishing tutor insight? Psychology Learning and Teaching, 4(1), 15-21.

Sander, P. (2009). Current Developments in Measuring Academic Behavioural Confidence. Psychology Teaching Review, 15(1), 32-44.

Sander, P. \& Sanders, L. (2003). Measuring confidence in academic study: A summary report. Electronic Journal of research in Educational Psychology and Psychopedagogy, l(1).

http://www.investigacion-psicopedagogica.org/revista/articulos/1/english/Art_1_1.pdf

Sander, P. \& Sanders, L. (2006). Understanding Academic Confidence. Psychology Teaching Review, 12, 1, 29-39.

Sander, P. \& Sanders, L. (2009). Measuring Academic Behavioural Confidence: The ABC Scale Revisited. Studies in Higher Education, 34(1), 19-35.

Sander, P., de la Fuente Arias, J., Stevenson, K. \& Jones, T. (2011). The Validation of the Academic Behavioural Confidence Scale with Spanish Psychology Student. Psychology Learning and Teaching, 10(1), 11-24

Sander, P., Stevenson, K., King, M. \& Coates, D. (2000). University Students' Expectations of Teaching. Studies in Higher Education, 25(3), pages 309 - 323

Sanders, L., Sander, P., \& Mercer, J. (2009). Rogue males. Perceptions and performance of male psychology students. Psychology Teaching Review 15(1), 3-17.

Shkodriani, G.M. \& Gibbons, J.L. (1995). Individualism and Collectivism Among University Students in Mexico and the United States. Journal of Social Psychology, 135(6), 765-772.

Smith, P. B., Bond, M. H., \& Kagitcibasi, C. (2006). Understanding social psychology across cultures: Living and working in a changing world. London: Sage.

Somners, E., \& Lawrence, S. (1992). Women's ways of talking in teacher-directed and student-directed peer response groups. Linguistics and Education, 4(1)-36.

SPSS for Windows, Rel. 17.0. Chicago: SPSS Inc.

Sternglanz, S. H., \& Lyberger-Ficek, S. (1977). Sex differences in student-teacher interactions in the college classroom. Sex Roles, 3(4), 345-352.

Tabachnick, B. G. \& Fidell, L. S. (2007). Using Multivariate Statistics. Pearson Education.

Tafarodi, R. W., \& Walters, P. (1999). Individualism-Collectivism, life events, and selfesteem: A test of two trade-offs. European Journal of Social Psychology, 29, 797-814

Top Universities (2010). QS World University Rankings. Available on line at http://www.topuniversities.com/university-rankings/world-university-rankings/2010 
Tuirán, R. (2011a). La educación superior: escenarios y desafíos futuros. Este País, 1st March, 2011. Retrieved on April 4th, 2011 from http://estepais.com/site/?p=32598

Tuirán, R. (2011b). La educación superior en México: avances, rezagos y retos. Retrieved on April 4th, 2011 from

http://ses4.sep.gob.mx/wb/ses/la_educacion_superior_en_mexico_avances_rezagos_y

VonDras, D. D. (2005). Influence of Individualism-Collectivism on learning barriers and self-efficacy of performance ratings in an introductory life-span development course. Paper presented at the Annual Meeting of the American Psychological Society. Retrieved April 4, 2011, from http://www.uwsa.edu/opid/abstracts/wtf04-05_VonDras.pdf

Zusho, A., Pintrich, P. R., \& Coppola, B. (2003). Skill and will: The role of motivation and cognition in the learning of college chemistry. International Journal of Science Education, 25(9), 1081-1094. 


\section{Appendix A}

\begin{tabular}{|c|c|c|c|c|c|c|}
\hline & Academic Behavioural Confidence Scale & \multirow{2}{*}{\multicolumn{5}{|c|}{$\begin{array}{l}\text { Escala De Confianza En La Conducta Académica } \\
\text { Esta escala se compone de varios enunciados sobre la } \\
\text { confianza que posees en tu conducta académica durante } \\
\text { esta asignatura. Elige la opción más correcta de cada } \\
\text { enunciado según el grado de seguridad para actuar como } \\
\text { se indica. }\end{array}$}} \\
\hline & $\begin{array}{l}\text { How confident are you that you will be able } \\
\text { to: }\end{array}$ & & & & & \\
\hline & 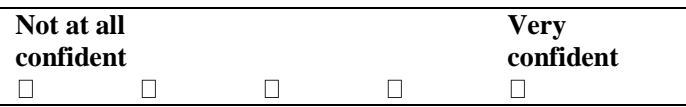 & $\begin{array}{c}\text { Nada } \\
1\end{array}$ & $\begin{array}{c}\text { Poco } \\
2\end{array}$ & $\begin{array}{c}\text { Regular } \\
3 \\
\end{array}$ & $\begin{array}{c}\text { Bastante } \\
4\end{array}$ & $\begin{array}{c}\text { Mucho } \\
5\end{array}$ \\
\hline 1. & $\begin{array}{l}\text { Study effectively on your own in independent / } \\
\text { private study }\end{array}$ & \multicolumn{5}{|c|}{ Estudiar solo/a de forma eficaz. } \\
\hline 2. & $\begin{array}{l}\text { Produce your best work under examination } \\
\text { conditions }\end{array}$ & \multicolumn{5}{|c|}{ Obtener tu mejor rendimiento en los exámenes. } \\
\hline 3. & $\begin{array}{l}\text { Respond to questions asked by a lecturer in } \\
\text { front of a full lecture theatre }\end{array}$ & \multicolumn{5}{|c|}{$\begin{array}{l}\text { Responder a las preguntas del profesor/a en un aula llena } \\
\text { de gente. }\end{array}$} \\
\hline 4. & $\begin{array}{l}\text { Manage your work load to meet coursework } \\
\text { deadlines }\end{array}$ & \multicolumn{5}{|c|}{$\begin{array}{l}\text { Administrar tu tiempo para cumplir las fechas límite en la } \\
\text { entrega de los trabajos de clase. }\end{array}$} \\
\hline 5. & $\begin{array}{l}\text { Give a presentation to a small group of fellow } \\
\text { students }\end{array}$ & \multicolumn{5}{|c|}{$\begin{array}{l}\text { Realizar una exposición ante un grupo pequeño de com- } \\
\text { pañeros. }\end{array}$} \\
\hline 6. & Attend most taught sessions & \multicolumn{5}{|c|}{ Asistir a la mayoría de las clases. } \\
\hline 7. & Attain good grades in your work & \multicolumn{5}{|c|}{ Lograr buenas notas en tus trabajos. } \\
\hline 8. & $\begin{array}{l}\text { Engage in profitable academic debate with } \\
\text { your peers }\end{array}$ & \multicolumn{5}{|c|}{$\begin{array}{l}\text { Tomar parte en debates académicos provechosos con tus } \\
\text { compañeros. }\end{array}$} \\
\hline 9. & $\begin{array}{l}\text { Ask lecturers questions about the material they } \\
\text { are teaching, in a one-to-one setting }\end{array}$ & \multicolumn{5}{|c|}{$\begin{array}{l}\text { Hacer preguntas al profesor/a, en situaciones de tú a tú, } \\
\text { acerca de la materia impartida. }\end{array}$} \\
\hline 10. & $\begin{array}{l}\text { Ask lecturers questions about the material they } \\
\text { are teaching, during a lecture }\end{array}$ & \multicolumn{5}{|c|}{$\begin{array}{l}\text { Hacer preguntas al profesor/a, durante una clase, acerca } \\
\text { de la materia impartida. }\end{array}$} \\
\hline 11. & $\begin{array}{l}\text { Understand the material outlined and discussed } \\
\text { with you by lecturers. }\end{array}$ & \multicolumn{5}{|c|}{ Entender la materia explicada por el profesor/a. } \\
\hline 12. & Follow the themes and debates in lectures. & \multicolumn{5}{|c|}{ Seguir los temas y debates de las clases. } \\
\hline 13. & Prepare thoroughly for tutorials. & \multicolumn{5}{|c|}{ Prepararse a fondo y asistir a las tutorías. } \\
\hline 14. & Read the recommended background material. & \multicolumn{5}{|c|}{ Leer el material complementario recomendado. } \\
\hline 15. & Produce coursework at the required standard. & \multicolumn{5}{|c|}{ Realizar el trabajo de clase de la manera requerida. } \\
\hline 16. & Write in an appropriate academic style. & Redact & on un & lo académ & apropiado & \\
\hline 17. & Ask for help if you don't understand. & Pedir a & la si no & tiendes al & & \\
\hline 18. & Be on time for lectures. & Llegar & itual a & clases. & & \\
\hline 19. & $\begin{array}{l}\text { Make the most of the opportunity of studying } \\
\text { for a degree at university }\end{array}$ & $\begin{array}{l}\text { Aprove } \\
\text { diar un }\end{array}$ & $\begin{array}{l}\operatorname{ar} \text { las c } \\
\operatorname{arrera}\end{array}$ & $\begin{array}{l}\text { tunidades } \\
\text { Universi }\end{array}$ & se presen & ara estu- \\
\hline 20. & Pass assessments at the first attempt. & Aprob & as eval & ones a la & era. & \\
\hline 21. & Plan appropriate revision schedules. & Progra & la rev & n de hora & apropiada & \\
\hline 22. & Remain adequately motivated throughout. & Manter & una $\mathrm{m}$ & ación ade & a hasta el & \\
\hline 23. & $\begin{array}{l}\text { Produce your best work in coursework assign- } \\
\text { ments }\end{array}$ & Obtene & uenos & ltados en & areas. & \\
\hline 24. & Attend tutorials & Asistir & as tuto & (clases pr & as). & \\
\hline
\end{tabular}




\section{Appendix B. The final 14 item ABC scale with subscales}

\begin{tabular}{|c|c|c|}
\hline & $\begin{array}{l}\text { Academic Behavioural Confi- } \\
\text { dence Scale }\end{array}$ & $\begin{array}{l}\text { Escala de Confianza en la Conducta } \\
\text { Académica }\end{array}$ \\
\hline $\begin{array}{l}\text { Verbalising } \\
\text { Verbalización }\end{array}$ & $\begin{array}{l}\text { Respond to questions asked by a } \\
\text { lecturer in front of a full lecture } \\
\text { theatre }\end{array}$ & $\begin{array}{l}\text { Responder a las preguntas del profesor/a } \\
\text { en un aula llena de gente. }\end{array}$ \\
\hline $\begin{array}{l}\text { Studying } \\
\text { Estudios }\end{array}$ & $\begin{array}{l}\text { Manage your work load to meet } \\
\text { coursework deadlines }\end{array}$ & $\begin{array}{l}\text { Administrar tu tiempo para cumplir las } \\
\text { fechas límite en la entrega de los trabajos } \\
\text { de clase. }\end{array}$ \\
\hline $\begin{array}{l}\text { Attendance } \\
\text { Asistencia }\end{array}$ & Attend most taught sessions & Asistir a la mayoría de las clases. \\
\hline $\begin{array}{l}\text { Grades } \\
\text { Notas }\end{array}$ & Attain good grades in your work & Lograr buenas notas en tus trabajos. \\
\hline $\begin{array}{l}\text { Verbalising } \\
\text { Verbalización }\end{array}$ & $\begin{array}{l}\text { Engage in profitable academic } \\
\text { debate with your peers }\end{array}$ & $\begin{array}{l}\text { Tomar parte en debates académicos pro- } \\
\text { vechosos con tus compañeros. }\end{array}$ \\
\hline $\begin{array}{l}\text { Verbalising } \\
\text { Verbalización }\end{array}$ & $\begin{array}{l}\text { Ask lecturers questions about the } \\
\text { material they are teaching, during } \\
\text { a lecture }\end{array}$ & $\begin{array}{l}\text { Hacer preguntas al profesor/a, durante } \\
\text { una clase, acerca de la materia impartida. }\end{array}$ \\
\hline $\begin{array}{l}\text { Grades } \\
\text { Notas }\end{array}$ & $\begin{array}{l}\text { Produce coursework at the re- } \\
\text { quired standard. }\end{array}$ & $\begin{array}{l}\text { Realizar el trabajo de clase de la manera } \\
\text { requerida. }\end{array}$ \\
\hline $\begin{array}{l}\text { Grades } \\
\text { Notas }\end{array}$ & $\begin{array}{l}\text { Write in an appropriate academic } \\
\text { style. }\end{array}$ & $\begin{array}{l}\text { Redactar con un estilo académico apro- } \\
\text { piado. }\end{array}$ \\
\hline $\begin{array}{l}\text { Attendance } \\
\text { Asistencia }\end{array}$ & Be on time for lectures. & Llegar puntual a las clases. \\
\hline $\begin{array}{l}\text { Grades } \\
\text { Notas }\end{array}$ & $\begin{array}{l}\text { Pass assessments at the first at- } \\
\text { tempt. }\end{array}$ & Aprobar las evaluaciones a la primera. \\
\hline $\begin{array}{l}\text { Studying } \\
\text { Estudios }\end{array}$ & $\begin{array}{l}\text { Plan appropriate revision schedu- } \\
\text { les. }\end{array}$ & $\begin{array}{l}\text { Programar la revisión de horarios apro- } \\
\text { piadamente. }\end{array}$ \\
\hline $\begin{array}{l}\text { Studying } \\
\text { Estudios }\end{array}$ & $\begin{array}{l}\text { Remain adequately motivated } \\
\text { throughout. }\end{array}$ & $\begin{array}{l}\text { Mantener una motivación adecuada hasta } \\
\text { el final. }\end{array}$ \\
\hline $\begin{array}{l}\text { Grades } \\
\text { Notas }\end{array}$ & $\begin{array}{l}\text { Produce your best work in } \\
\text { coursework assignments }\end{array}$ & Obtener buenos resultados en las tareas. \\
\hline $\begin{array}{l}\text { Attendance } \\
\text { Asistencia }\end{array}$ & Attend tutorials & Asistir a las tutorías (clases prácticas). \\
\hline
\end{tabular}

